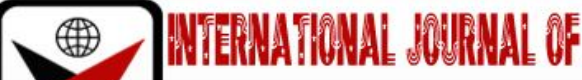

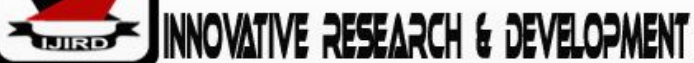

ISSN 2278 - 0211 (Online)

\section{Assessment of Broodstock Management Practices in Nigeria}

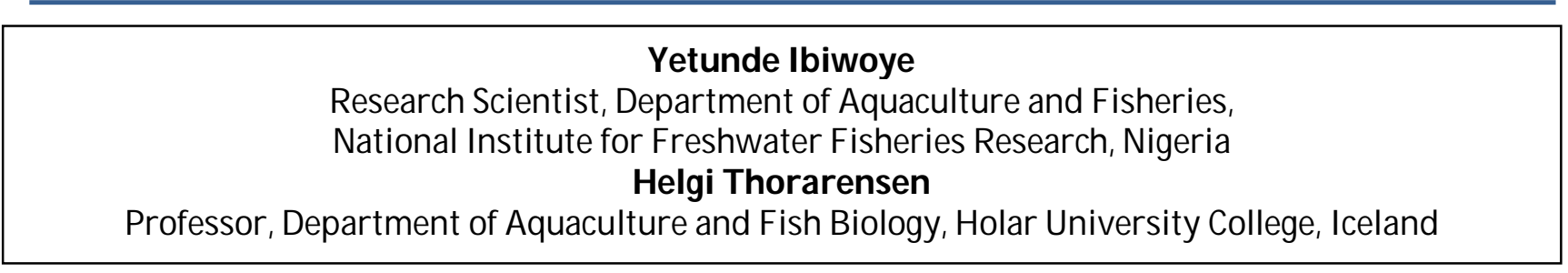

\begin{abstract}
:
Genetic management of African catfish broodstock is important to ensure the quality of seed. This study was conducted to identify and critically evaluate current broodstock management practises in African catfish hatcheries in Nigeria. A questionnaire was presented in 44 hatcheries in three main aquaculture regions in Nigeria and 34 responded. The results indicated that more than $50 \%$ of hatcheries keep fewer than 40 broodfish, with a higher ratio of females than males. This causes the effective breeding number to be under the recommended minimum value in many hatcheries and can result in genetic drift or inbreeding depression. However, the common practice of optioning broodfish regularly from different sources may reduce the risk of inbreeding depression. Only $6 \%$ of the hatcheries use broodstock raised on their farms only and this group is predisposed to problems due to poor genetic management. Most hatcheries use females that are 1-1.5 kg as broodfish. However, the results of the present study suggest that seed quality, quantity and survival could be increased significantly by using larger females. The results of the study were used to produce recommendations to improve broodstock management in Nigeria.
\end{abstract}

Keywords: Broodstock management, African catfish, juvenile quality, genetic management

\section{Introduction}

Aquaculture contributes significantly to the global fish supply (FAO, 2016) and increases the supply of fish while natural stocks are fished at or over maximum capacity (Daw, Adger, Brown, \& Badjeck, 2009). Sustainable growth of this sector is vital as the demand for fish increases with growing human population (Boyd, 2009). Fish account for about 17 percent of the global animal protein intake for humans (FAO, 2014). Due to the dynamic growth in the aquaculture sector in recent times, it now accounts for 73.8 million tonnes (44 percent) out of a total of about 167.2 million tonnes of world fish production (FAO, 2016). Aquaculture is currently the fastest growing food producing sector(FAO, 2016) and it is predicted that by 2030 it will supply $62 \%$ of world food fish (World bank, 2014) with the fastest growth likely in tilapia, carp, and catfish production (FAO, 2014).

Aquaculture production in Africa only contributes $2 \%$ of the world total aquaculture production. In the near future, aquaculture production in Africa is expected to increase substantially as income levels rise and the populations expand (World bank, 2013). Nigeria is the second largest producer in Africa after only Egypt (FAO, 2017).Other main aquaculture producing countries in Africa are Uganda, Ghana, Kenya, Zambia, Madagascar and South Africa.

Natural conditions favour aquaculture production in Nigeria since the average temperature is high and the country has abundant water resources (Ukuedojor, 2013). The history of aquaculture in Nigeria can be traced back to1951 when the pioneer aquaculture facility, Panyam fish farm, in the Plateau State was founded (Ajayi, 1971). Then, the practice of aquaculture was a government-driven venture, but in recent years, aquaculture in Nigeria is primarily a private venture affair (FAO, 2017) and most of the farms, fish feed industry, broodstock farms and hatcheries are owned by private organizations. Aquaculture fish species farmed in Nigeria include catfish (Clarias gariepinus, Heterobranchus longifilis, and H. bidorsalis), tilapia (Oreochromis niloticus, O.mossambicus, O. aureus) and carp (Cyprinus carpio). However, African catfish constitutes more than $60 \%$ and tilapia about $9 \%$ of the total aquaculture production in Nigeria. The production system is primarily ponds (earthen or concrete) and tanks.

Annual domestic fish supply from small scale and industrial fishing were about 710,500 Mt, while aquaculture supplied about 317,000 Mt in the year 2015 (Nigeria Bureau of statistics., 2015). In addition to the local production, it is estimated that over 700,000 tonnes of fish are imported (FDF, 2008). accounting for 41\% of total fish supply. Therefore, Nigerian capture fisheries (both small scale and industrial captured fisheries) make up 41\% of the fish supply, aquaculture accounts for $18 \%$ and imports for $41 \%$ of the fish supply in Nigeria (Figure 1). 


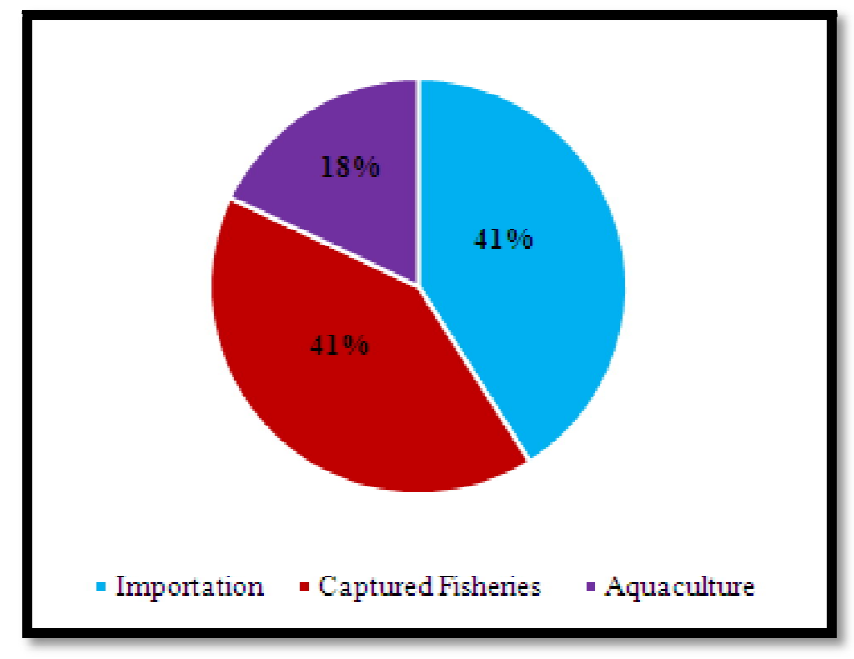

Figure 1: Sources of Fish Supply in Nigeria

(Nigeria Fishery Statistics, 2016)

Total fish demand for Nigeria based on the 2014 population estimate of 180 million people is 3.32 million Mt. (Nigeria Fishery Statistics, 2016) which is far more than the current supply. This implies that the demand for aquaculture product in Nigeria is significant and increasing because of the growing population in the country. This creates good opportunities for aquaculture growth in Nigeria.

Several strategies have been adopted by the Government of Nigeria to encourage increase domestic fish production which comprise of the introduction of the Federal Government Growth Enhancement Support Scheme by distributing inputs such as catfish juveniles, fish feed, nets etc at a subsidized price to fish farmers across the country. Furthermore, a brood stock production and seed multiplication project was recently initiated by the West Africa Agricultural Productivity Programme (WAAPP) in collaboration with Federal government research institutions and private hatcheries (WAAPP, 2017) to increase the quality of seed for aquaculture in the country.

In spite of all the strategies adopted to support the growth of aquaculture, the aquaculture industry is confronted with several lingering challenges such as the inadequate supply of good quality seed, poor management skills, the high cost of feed, lack of capital and faulty data collection (Adewumi \& Olaleye, 2011). The poor management practices of brood stock include too little feeding, handling stress (Shourbela, Abd El-latif, \& Abd El-Gawad, 2016), lack of record keeping about the source, age and family line of the brood stock (Little, Satapornvanit, \& Edward, 2002).These practices could in future lead to inbreeding and, as a result, poor-quality fish seed.

\subsection{Objectives of the Study}

The aim of this study was to evaluate the methods used for brood stock management and suggest possible improvement practises that can enhance the quality of fish seed production. To achieve this objective, the following tasks were carried out:

- Current practices and challenges in broodstock management in Nigeria were identified.

- Current practices in broodstock management in Nigeria were critically evaluated.

- Recommendations to improve broodstock management in Nigeria were provided based on the results of the study.

\section{Methodology}

This study was done to assess the status of broodstock management in Nigeria. The assessment was performed through a structured questionnaire and interviews undertaken by fisheries officers. The questionnaire addressed important areas for brood stock management such as; fecundity, survival, hatchability, feeding routine, brood stock source and brood stock selection methods.

\subsection{Study Area}

The fisheries officers visited 34 African catfish broodstock farms and hatcheries and administered the questionnaire. Although about 44 hatcheries where initially contacted, only 34 responded. The hatcheries contacted had been in operation for a minimum of 5 years and they were selected randomly in the three main aquaculture regions in Nigeria - The North central zone, South west zone and South-East zone (Figure 2). 


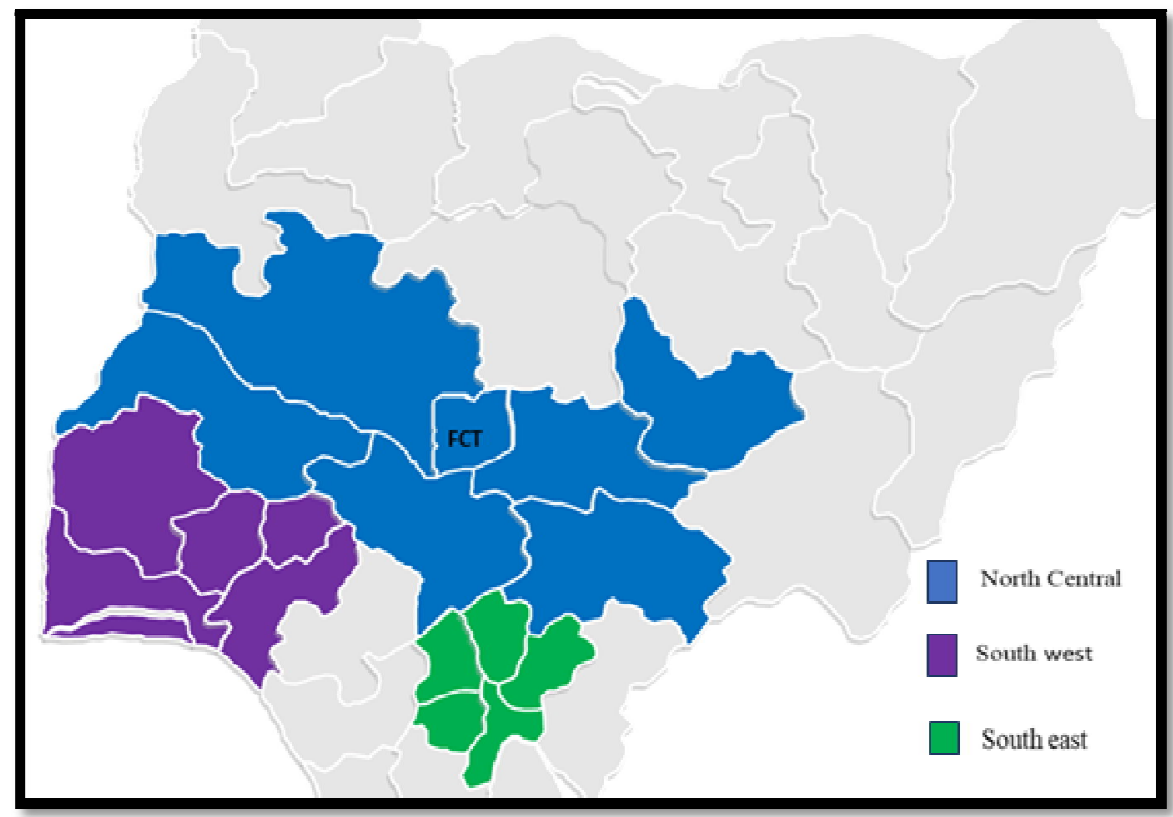

Figure 2: Map of Nigeria Showing the Study Area

\subsection{Implementation of Questionnaire}

The questionnaire was sent to fisheries officers who conducted the interviews with catfish hatchery owners or managers. The responses were recorded and entered into Google documents where they could be accessed. During the interviews, questions were asked about selection methods, the frequency of spawning female, fecundity, hatchability of eggs, survival rate, feed quality, feeding routine and other challenges faced by fish breeders.

\subsection{Analysis of the Questionnaire}

The questionnaire contained both open ended and closed questions. The open-ended questions were summarized while the responses to the closed questions were analysed using Ms excel 2016 with the Data analysis tool pack.

\section{Results}

Information obtained from the respondents on the management practices of African catfish broodstock in Nigeria are summarised and illustrated below:

\subsection{Sources of Broodstock}

Most catfish hatcheries, about $70 \%$ source brood stock from other farms and several other sources and $21 \%$ obtain broodstock from the wild and from other sources (Figure 3). However, relatively few (6\%) use only their own broodstock and this is group is more disposed to inbreeding depression and genetic drift.

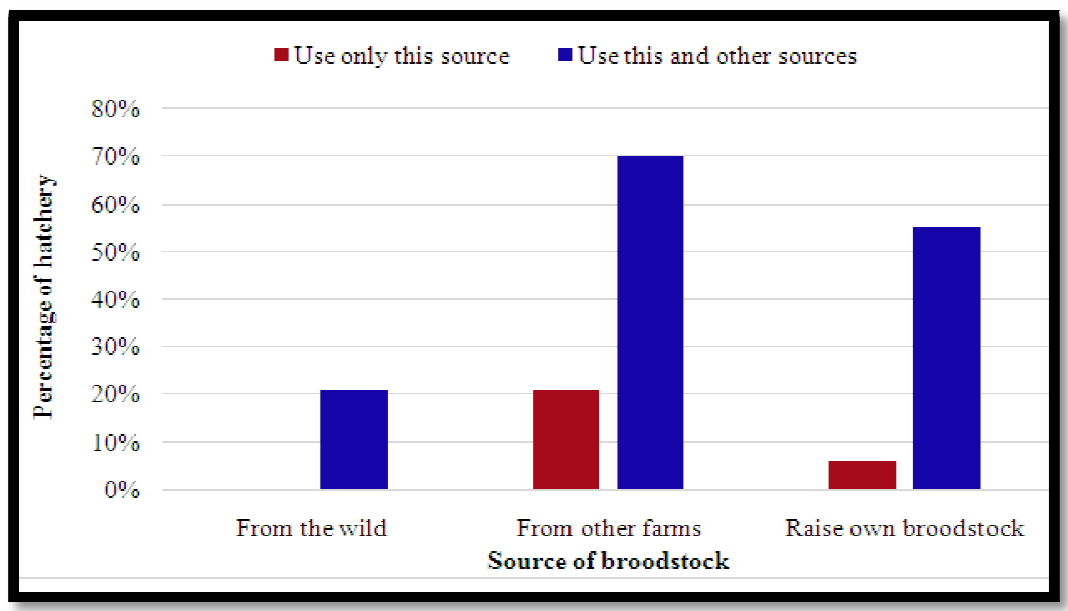

Figure 3: Sources of Brood Stock

\subsection{Number of Brood Fish in the Hatchery}

Around $29 \%$ of the catfish hatcheries keep less than 20 broodfish in the hatcheries, $53 \%$ keep less than 40 broodfish and $71 \%$ keep less than 60 broodfish. In total, $24 \%$ of the farms keep 61-150 broodfish and only 6\% keep above 200 broodfish (Figure 4). 


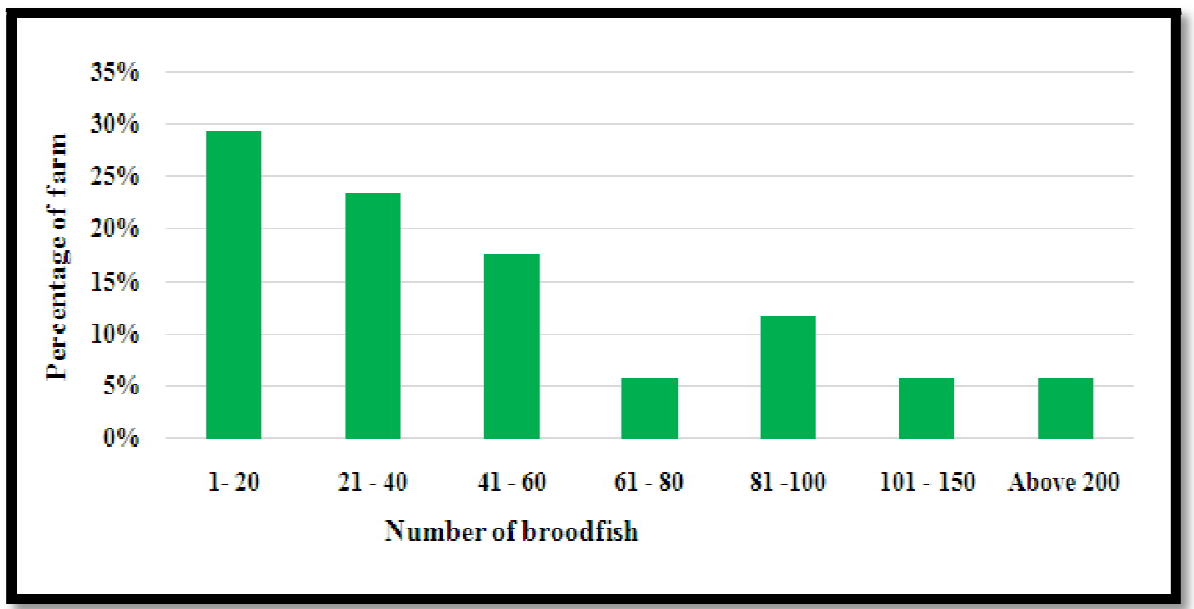

Figure 4: Number of Brood Fish in the Hatcheries

\subsection{Effective Breeding Number $\left(\mathrm{N}_{\mathrm{e}}\right)$}

It was not possible to estimate the $\mathrm{N}_{\mathrm{e}}$ and the Fish in individual hatcheries based on the information provided in the questionnaire. However, the overall effective breeding number was estimated based on the number of fishes in broodstock and the sex ratio (Figure 5). Based on the number of broodfish kept (Figure 5) and the female to male ratio, it is expected that the $\mathrm{N}_{\mathrm{e}}$ in more than half of the hatcheries is less than 40 and even as little as 20 in some.

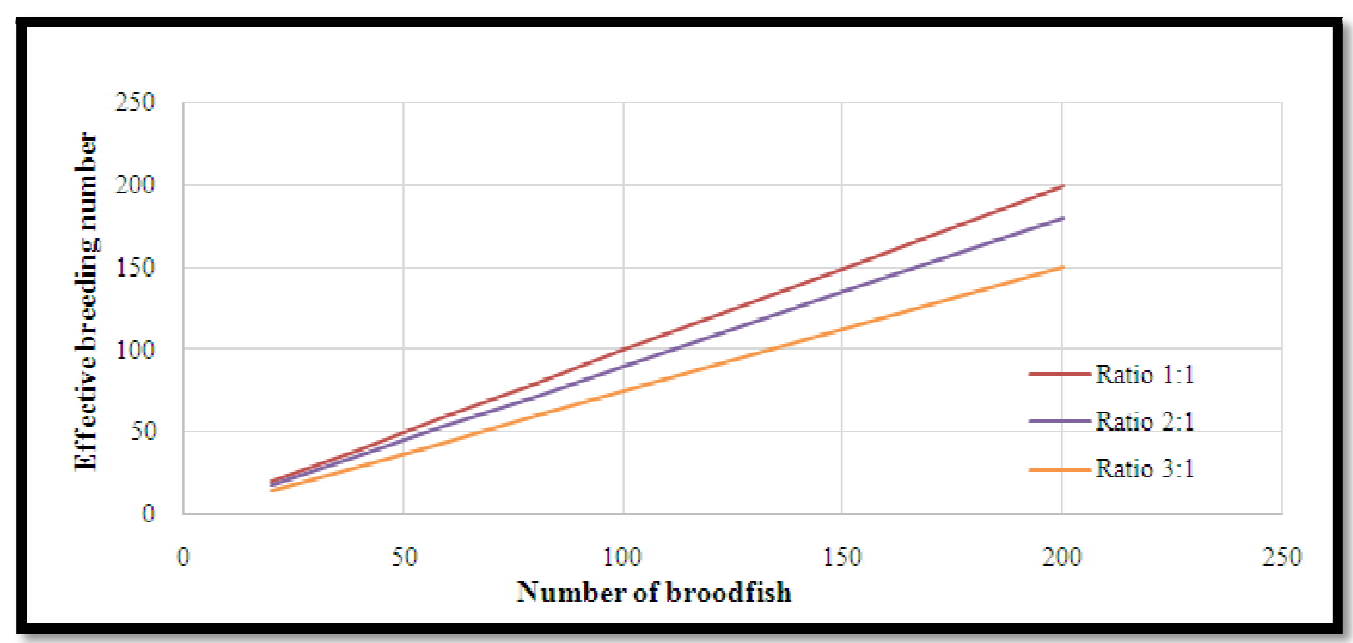

Figure 5: Effective Breeding Number $\left(\mathrm{N}_{\mathrm{e}}\right)$

\subsection{Weight of Brood Fish}

The most common size of broodstock used for catfish fingerlings production was between $1.6 \mathrm{~kg}$ and $2 \mathrm{~kg}(59 \%)$ (Figure 6). About 18\% use fish weighing less than $1.6 \mathrm{~kg}$, while $24 \%$ use larger fish weighing above $2 \mathrm{~kg}$.

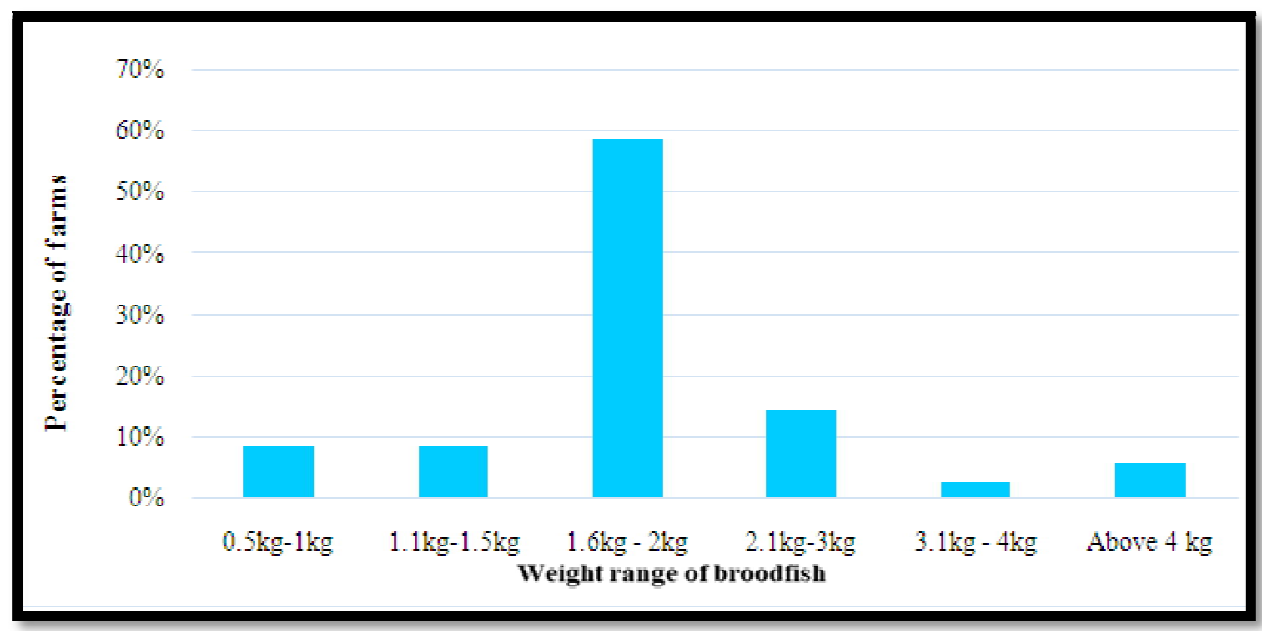

Figure 6: Weight Range of Brood Fish 


\subsection{Weight of Spawned Eggs}

About $44 \%$ of the hatcheries do not measure the weight of egg spawned. Of those that record egg weight, 18\% reported that they obtain between 100 and $250 \mathrm{~g}$ of egg, while $26 \%$ obtain about $251-500 \mathrm{~g}$ and just about $12 \%$ more than $500 \mathrm{~g}$ of eggs (Figure 7).

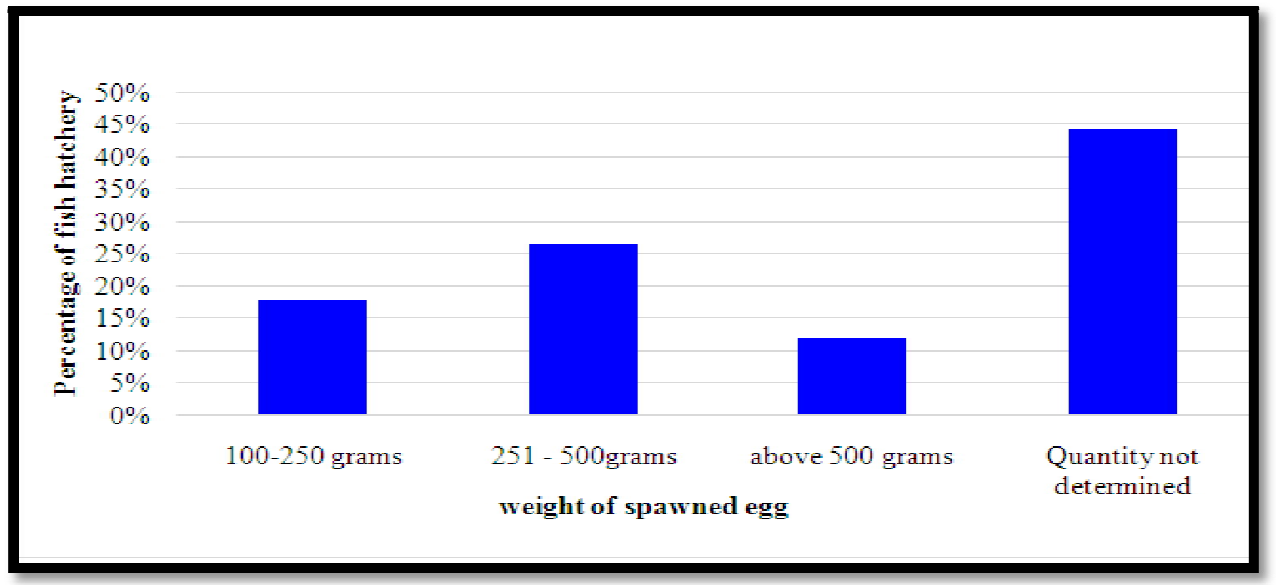

Figure 7: Total Weight of Spawned Eggs

\subsection{Survival Rate of Juveniles}

The survival rate was estimated by subtracting the total number of juveniles from the total number of larvae from first feeding. The survival rate is usually determined at about 6 weeks from date of hatching. A survival rate of juveniles between $60-80 \%$ was reported in $46 \%$ of the hatcheries, $42 \%$ reported $40-60 \%$ survival rate while $13 \%$ reported above $80 \%$ survival rate from hatching to juveniles (Figure 8).

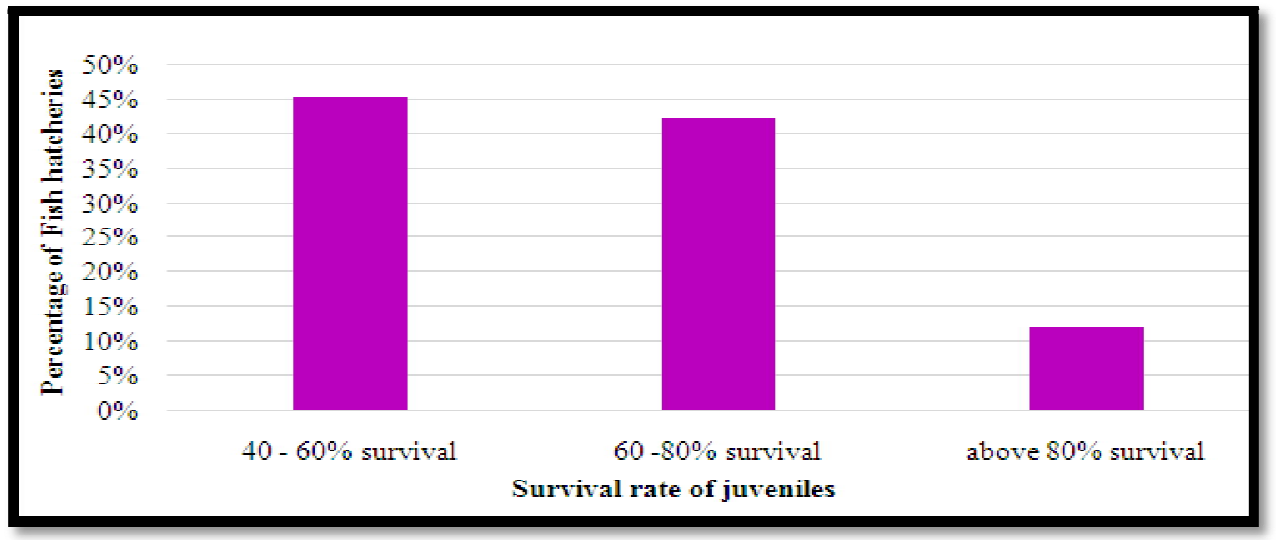

Figure 8: Survival Rate of Juveniles in Fish Hatcheries

3.7. Relationship between Weight of Female Broodfish, Weight of Eggs and Survival Rate of Juveniles

There was a significant linear relationship between the weight of eggs and weight of female broodfish, (Figure 9) and the total weight of eggs increased with increasing weight of females $(p=0.01)$.

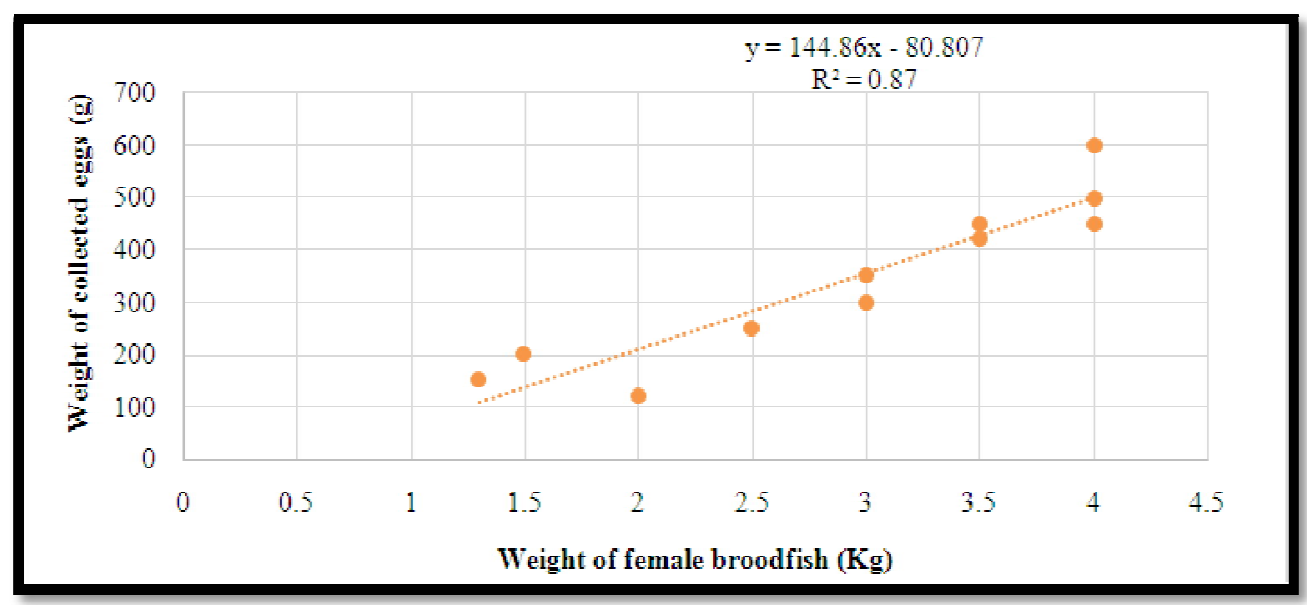

Figure 9: Relationship between Weight of Female Brood fish and Weight of Collected Eggs 
There was also a significant relationship between survival rate of juveniles and total mass of eggs collected $(p=$ 0.02), the survival rate of juveniles increases with an increase in the weight of eggs (Figure 10).

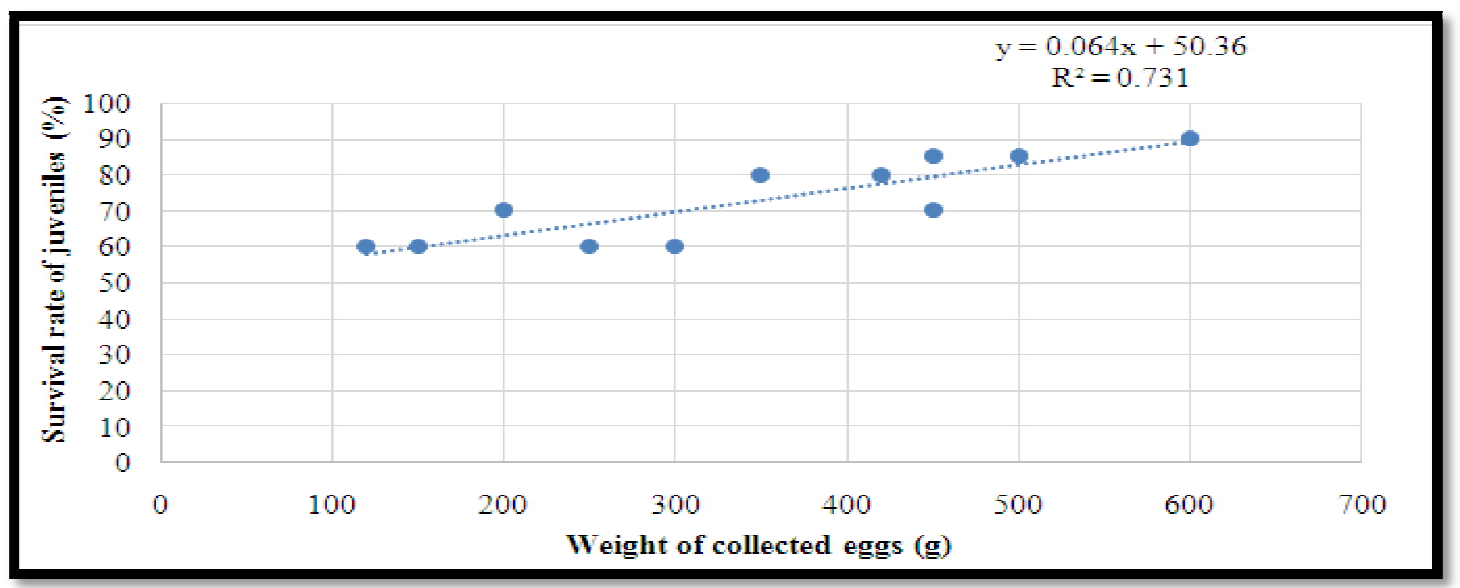

Figure 10: Relationship between Survival Rate of Fingerlings and Weight of the Collected Egg

The survival rate of juveniles increased with increasing size of female broodfish ( $p=0.001$ ). The best survival ( 85 $90 \%$ ) was recorded when female broodfish were $4 \mathrm{~kg}$ (Figure 11).

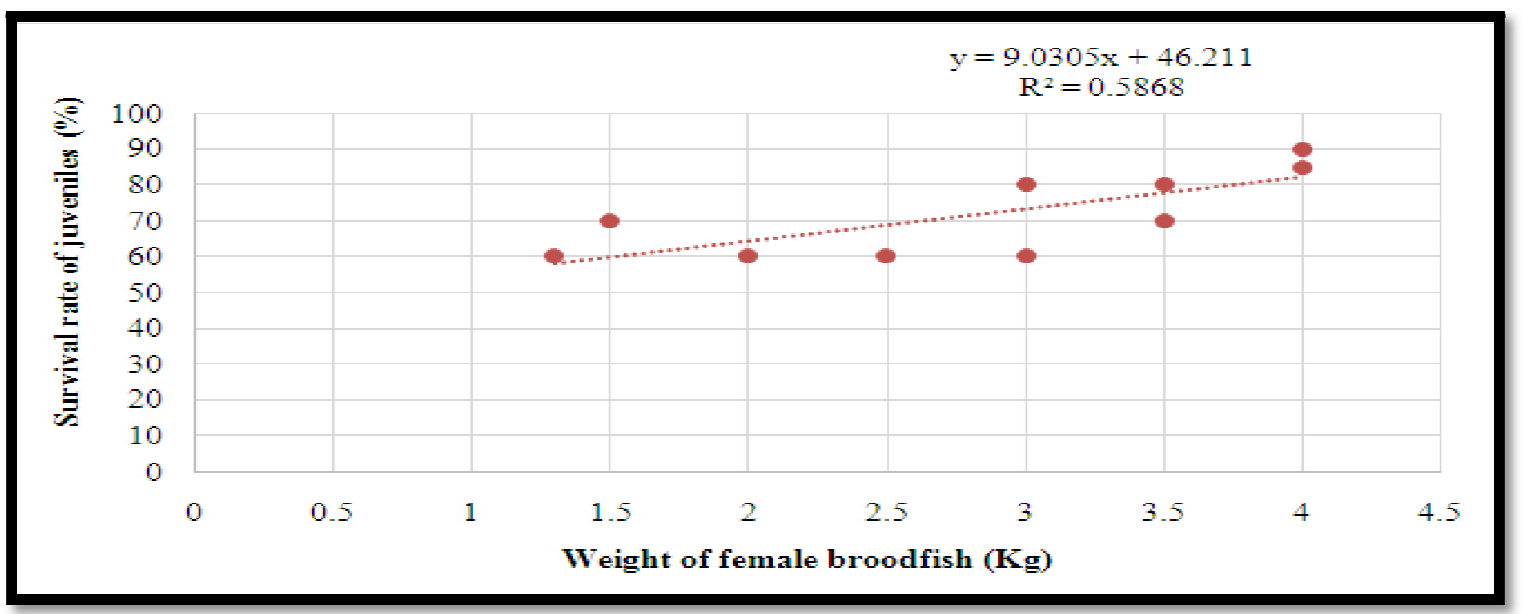

Figure 11: Relationship between Weight of Female Broodfish and Survival Rate of Juveniles

When the survival rate, the weight of broodfish and weight of eggs were analysed together. There appears to be auto correlation between survival rate, egg mass and the weight of females. This indicates that the weight of female broodfish affects egg mass and possibly also survival rate possibly through larger eggs of larger females although this was not measured.

\section{Discussion}

This is the first study to estimate hatchery management practices in Nigeria. The results suggest, in half of the hatcheries the number of broodfish and the $\mathrm{N}_{\mathrm{e}}$ are below the recommended levels 50 or higher. In some of the hatcheries the $\mathrm{N}_{\mathrm{e}}$ could even be 20 or lower (Figure 5). This could cause problems with inbreeding and genetic drift. The main reason for small breeding populations are likely high feeding costs. Similarly, to save money, most of the farms do not keep a female to male sex ratio 1:1 which further reduces the effective breeding number. Small effective breeding number increases the probability of genetic drift or inbreeding depression (Tave, 1999). Therefore, too low $\mathrm{N}_{\mathrm{e}}$ may be a problem in few (6\%), hatcheries (Figure 3) which have a closed population.

The common practice of obtaining broodstock from different sources (Figure 3) can counteract the low number of broodstock in hatcheries. This introduces new fish into the broodstock and, as a result, the probability of inbreeding depression can be reduced. The most common practise is to purchase large fish from farmers growing fish for food and keep the fish for some time to be used as broodstock. Unfortunately, the farmers cannot provide informationon the pedigree of the fish. However, this may not be a problem if the fish are sourced from different farms, which reduces the likelihood of inbreeding. The questionnaire did not give information on how frequently the hatcheries bring in new broodfish from external sources but that would be an interesting study area.

The results of this study show that bigger broodfish spawn a larger egg mass( Figure 9) Furthermore, results of other studies suggest that the better survival of seed from larger females found in the present study could be due to larger yolk reserve in the eggs from bigger female broodstock (Springate \& Bromage, 1985)(Marsh, 1986)(Hutching, 1991). As a result, eggs spawned from bigger females have better fertilization rate, bettersurvival of juveniles and produce better 
quality seed. Hatcheries that use female broodfish of $4 \mathrm{~kg}$ recorded about $38 \%$ better survival rate than hatcheries that use small female broodfish. This is in line with the results of (Jokthan, 2013)(Roff, 1992)who found that heavier females produced a better quantity of eggs and recorded higher fertilization rate and better survival than smaller females. The findings are also in accord with those of (Bichi, Isyaku, Danba, Kurawa, \& Nayawo, 2014), which suggested that egg size determined most of the variation in final juvenile fitness and that larger eggs came from larger females which in turn produced larger juveniles.

The weight range of broodfish reported in the present study was between 1.6 to $2 \mathrm{~kg}$,although, some farms use larger broodfish weighing up to $4 \mathrm{~kg}$ (Figure 6). As described above, the results of the present study suggest that heavier broodfish spawn more and better-quality eggs, which could increase the survival of the eggs and juveniles. These results are similar to those of (Jesse, 2008)(Jokthan, 2013) that suggested that females weighing between 1.8 and 3.6kg spawn eggs of better quality than smaller females and similar results were also reported by (Sule \& Adikwu, 2004). Therefore, the quality of catfish eggs and seed in Nigeria could be increased significantly by using larger broodfish.

Based on discoveries, a future goal for Nigeria may be to set up a breeding program for African catfish. Breeding programs are expensive to set up and run. It also requires facilities and technical expertise that the hatcheries lack. However, the gains from selective breeding in terms of growth rate and survival could be very significant. The cost of running a breeding program precludes smaller hatcheries to be involved. Instead the government or larger private companies with the technical expertise and financial capacity could run such a program and only one central program should be set up in the country.

\section{Conclusion}

Even though too small breeding numbers may be a potential problem in catfish hatcheries in Nigeria, the common practise of obtaining broodfish from different sources can help to counteract the negative effects of inbreeding depression. Only relatively few hatcheries use only their own broodstock and they are predisposed to inbreeding depression.

Secondly, the use of bigger female broodfish can improve the size, number and quality of eggs spawned, as well as hatching success, survival rate and quality of fish seed produced.

\section{Recommendation}

Under the present conditions, hatcheries in Nigeria should obtain their broodfish from different sources to reduce the risk of inbreeding depression and genetic drift.

Hatcheries are also encouraged to use larger females as broodfish to increase egg production and to improve the quality of fish seed.

It is recommended that fish hatchery managers and fish farmers adopt better record keeping on the pedigree of their broodfish so that this information can serve as a guide in the future selection of parent fish for breeding.

A breeding program should be set up to improve the performance of aquaculture catfish in terms of growth and survival. Broodstock from the breeding program can be produced and distributed among hatcheries across Nigeria. This is a task for the government or larger aquaculture companies.

\section{Acknowledgements}

My sincere gratitude to Dr. Tumi Tomasson, Director of the UNU-FTP, Mr. Thor Asgeirsson, Deputy Director UNUFTP,Ms. Mary Frances Davidson, Ms. Julie Ingham, Mr Stefan Ulfarsson and all UNU-FTP staff for giving me the opportunity to attend this impactful capacity building course and for their untiring support. My sincere thanks to my supervisor, Professor Helgi Thorarensen, for his guidance and relentless contribution in shaping this project. I would also like to thank Olafur Sigurgeirsson, the Director and staff of Holar University College and the staff at VERID, Saudarkrokur for their contribution and hospitality during my stay in Iceland.

\section{References}

i. Adewumi, A. A., \& Olaleye, V. F. (2011). Catfish culture, prospects, progress and problems. African Journal of Agricultural Research, 6(6), 1281 - 1285.

ii. Ajayi, S. (1971). Panyam fish farm and the introduction of European Carp (Cyprinus Carpio). Nigerian Field, 36:2331.

iii. Bichi, A. H., Isyaku, S., Danba, E. P., Kurawa, I. A., \& Nayawo, A. (2014). Effect of broodstock size on egg fertilization,hatchability and frr suvival rate of African catfish. Bayero Journal of Pure and Applied Sciences, 7 (2), 150 - 154 . Retrieved from http:/ / dx.doi.org/ 10.4314/ bajopas.v7i2.26

iv. Boyd, C. (2009). Aquaculture, Freshwater. Encyclopedia of Inland Waters. Reference Module in Earth Systems and Environmental Sciences, 2013, 234-241. doi:https:/ / doi.org/ 10.1016/ B978-012370626-3.00237-4

v. Cerda, J., Carrillo, M., Zanuy, S., Ramos, J., \& de la Higuera. (1994). Influence of nutritional composition of diet on sea bass, Dicentrarchus labrax L., reproductive performance and egg and larval quality. Aquaculture, 128(3-4):, 345-361.

vi. Daw, T., Adger, W., Brown, K., \& Badjeck, M.-C. (2009). Climate change and capture fisheries: potential impacts, adaptation and mitigation. In K. Cochrane, C. De Young, D. Soto and T. Bahri (eds). Climate change implications for fisheries and aquaculture: overview of current scientific knowledge. Rome,: FAO.

vii. FAO. (2014). the state of World Fisheries and Aquaculture. Report by FAO, Fisheries and Aquaculture department. FAO. 
viii. FAO. (2016). the State of World Fisheries and Aquaculture. Contributing to food security and nutrition for all, 200 pp.

ix. FAO. (2017). Fishery and Aquaculture Country Profiles. Nigeria (2007). Country Profile Fact Sheets. 1 November 2017.

x. FDF. (2008). Fisheries statistics of Nigeria. The projected human population, Fish Demand and Supply in Nigeria. Federal Department of Fisheries, Nigeria.

xi. George, F. O., Olaoye, O. J., Akande, O. P., \& Oghobase, R. R. (2010). Determinants of Aquaculture Fish Seed Production and Development in Ogun State, Nigeria. Journal of Sustainable Development in Africa, 12, 22 - 34.

xii. Hutching, J. (1991). Fitness consequencies of variation in Egg size and food abundance in brook trout salvelinusfontinalis. Evolution, 45:, 1162-1168.

xiii. Jesse, A. C. (2008). Practical Channel Catfish Brood stock Selection and Management. Revised 2008.

xiv. Jokthan, G. E. (2013). Effect of Age of Spawned Catfish (Clarias Gariepinus) Broodstock on Quantity of Eggs and Mi Figure lt Produced and GrowthPerformance of Fry. IOSR Journal of Agriculture and Veterinary Science (IOSRJAVS), 5(3), PP 59-61.

xv. Little, D. C., Satapornvanit, A., \& Edward, P. (2002). Freshwater Fish seed in Asia. p 185 - 196. In Rural Aquaculture. Wallingford: CABI Publishing.

xvi. Marsh, E. (1986). Effect of egg size of offspring fitness and maternal fecundity in the orange-throat darter Etheostomaspectabile (Pisces: percidae).. Copeia. 1986:, 18-30.

xvii. Nigeria Bureau of statistics. (2015). Nigeria's Fish Production report for 2010-2015.

xviii. Nigeria Fishery Statistics. (2016). Fishery Committee for West Central Gulf of Guinea. Annual report.

xix. Okanlawon, S. S. (2010, May 29). Reproductive Fitness of Stressed Female Catfish Broodstock of Clarias gariepinus (Burchell, 1822). Production Agriculture and Technology, PAT June, 2010; 6 (1):, 77-83.

xx. Ozigbo, E., Anyadike, C., Adegbite, O., \& Kolawole, P. (2014). Review of Aquaculture Production and Management in Nigeria. American Journal of Experimental Agriculture. 4(10):, 1137-1151.

xxi. Roff, D. A. (1992). The Evolution of life history. Champman and Hall, New York.

xxii. Shourbela, R. M., Abd El-latif, A. S., \& Abd El-Gawad, E. M. (2016). Are Pre Spawning Stressors Affect Reproductive Performance of African Catfish Clarias gariepinus? Turkish Journal of Fisheries and Aquatic Sciences, 16:, 651-657. doi:DOI: 10.4194/ 1303-2712-v16 319

xxiii. Springate, J. C., \& Bromage, N. R. (1985). Effect of egg size on early growth and survival in rainbow trout (Salmon gairdneri Richardson) Aquaculture, 47: 163-172.

xxiv. Sule, O. D., \& Adikwu, I. A. (2004). Effect of brood stock size on egg and larval size and survival of larvae of African Catfish, C. gariepinus under laboratory conditions. Journal of Aquatic sciences, 19(1), 1-4.

xxv. Tave, D. (1999). Inbreeding and brood stock management (Vol. 392). Rome.

xxvi. Ukuedojor, M. (2013, January Saturday, 05). Adequate drinking water still a tall dream in Nigeria. . Published on Saturday, 05 January 2013. Retrieved December 07, 2013

xxvii. USDA. (2014). Report on Assessments of Commodity and Trade Issues: Fishery product. . April 2014. Global Agricultural Information Network- GAIN Report.

xxviii. WAAPP. (2017). West Africa Agricultural Productivity Programme-Nigeria. Abuja,Nigeria . Retrieved from http:/ / www.waapp.gov.ng

xxix. World Bank. (2013). Fish to 2030: Prospects of Fisheries and aquaculture. In Agricultural and Environmental Service discussion paper. Third edition. World Bank.

xxx. World Bank. (2014). Press Release: Fish Farms to Produce Nearly Two Thirds of Global Food Fish Supply by 2030, Report. 